\title{
USLUGE OD OPĆEG GOSPODARSKOG INTERESA U PRAVU EUROPSKE UNIJE I HRVATSKI REGULATORNI OKVIR U ODABRANIM UPRAVNIM PODRUČJIMA
}

Doc. dr. sc. Tomislav Sokol*

Izv. prof. dr. sc. Frane Staničic **
UDK: 351.82: 35.078.3(4)EU

35.078.3(497.5)

339:923.061.1>(4)EU

DOI: 10.3935/zpfz.69.56.08

Izvorni znanstveni rad

Primljeno: studeni 2019.

Usluge od općeg gospodarskog interesa složena su sfera prava. Predstavljaju iznimno važan dio trgovine na unutarnjem tržištu Europske unije te gospodarstva EU-a u cjelini. One obuhvaćaju vrlo širok spektar ljudskih djelatnosti i prisutne su u svim sferama naših života. Među njih pripadaju usluge oko čije gospodarske prirode nema nikakvih dilema, ali i one čiji je način organiziranja i financiranja specifičan te je podložan posebnim pravnim rě̌imima, poput zdravstva, obrazovanja, javnog prijevoza $i$ slično. Ta posebna uloga odredenih vrsta usluga dovela je do definiranja koncepta "usluga od općeg gospodarskog interesa" u pravnom okviru Europske unije, s neizbježnim posljedicama na pravni okvir država članica EU-a, uključujući i Hrvatsku. One nisu u potpunosti definirane primarnim pravom EU-a, već je konkretno određivanje što predmetni pojam obuhvaća prepušteno autonomiji država članica. Navedena autonomija, međutim, nije apsolutna, već su okviri definirani pravom Unije, a ključan faktor pri određivanju ovih usluga predstavlja njihova gospodarska, odnosno negospodarska priroda, jer su usluge od općeg gospodarskog interesa podvrgnute tržišnim pravilima EU-a, za razliku od onih negospodarskih. Sudska praksa u ovom dijelu vrlo je složena te se primjenjivost tržišnih pravila utvrđuje kazuistički.

* Dr. sc. Tomislav Sokol, viši predavač Zagrebačke škole ekonomije i managementa, naslovni docent Hrvatskog katoličkog sveučilišta, Jordanovac 110, Zagreb; tsokol@ zsem.hr;

ORCID ID: orcid.org/0000-0002-3592-2967

** Dr. sc. Frane Staničić, izvanredni profesor Pravnog fakulteta Sveučilišta u Zagrebu, Sv. Ćirila i Metoda 4, Zagreb; frane.stanicic@pravo.hr;

ORCID ID: orcid.org/0000-0001-8304-7901 
U slučaju gospodarskih usluga kod kojih su zadovoljeni uvjeti iz predmeta Altmark, tržišna pravila EU-a uopće nisu primjenjiva i država može ovlastiti poduzetnika za pružanje usluge od općeg gospodarskog interesa $i$ dati mu financijsku potporu u tu svrhu. Drugo, ako tržišna pravila jesu primjenjiva, odstupanje nacionalnih pravila od tržišta ipak će se moći opravdati ako je to odstupanje nužno za ostvarenje cilja od općeg interesa radi kojeg se određena usluga pruža. Cilj ovog rada je analizirati pravni okvir Europske unije koji uređuje usluge od općeg gospodarskog interesa, odnos ovog koncepta prema pravilima o slobodi kretanja, zaštiti tržišnog natjecanja i državnim potporama na unutarnjem tržištu EU-a te utvrditi poštuje li Republika Hrvatska navedeni okvir i postoje li prijepori u domaćem upravnom pravu koje je potrebno pravno razriješiti.

Analiza odnosa pravnog okvira EU-a i hrvatskog upravnopravnog okvira $u$ pojedinim područjima pokazuje visok stupanj uskladenosti nacionalnog prava s tržišnim pravilima Unije. To je posebno slučaj u područjima koja su uredena detaljnijim pravilima (primjerice, o državnim potporama) sadržanim u sekundarnom zakonodavstvu EU-a. S druge strane, u područjima koja pripadaju u primarnu nadležnost država članica, poput zdravstva i obrazovanja, postoje određene dileme o uskladenosti nacionalnog i europskog prava. U nacionalnom zakonodavstvu koje uređuje potonje potrebno je napraviti jasnu distinkciju između gospodarskih i negospodarskih usluga od općeg interesa kako bi se povećala pravna sigurnost $i$ izbjegle sumnje o nelegalnom državnom favoriziranju javnih ustanova na štetu privatnih.

Ključne riječi: Altmark, obrazovanje, zdravstvo, prijevoz, usluge od općeg gospodarskog interesa

\section{UVOD}

Usluge predstavljaju iznimno važan dio trgovine na unutarnjem tržištu Europske unije i gospodarstva EU-a u cjelini. One obuhvaćaju vrlo širok spektar ljudskih djelatnosti te su prisutne u svim sferama naših života. Među njih pripadaju usluge oko čije gospodarske prirode nema nikakvih dilema, ali i one čiji je način organiziranja i financiranja specifičan te je podložan posebnim pravnim režimima, poput zdravstva, obrazovanja, javnog prijevoza i slično. Ta posebna uloga određenih vrsta usluga dovela je do definiranja koncepta "usluga od općeg gospodarskog interesa" u pravnom okviru Europske unije, s neizbježnim posljedicama na pravni okvir država članica EU-a, uključujući i Hrvatsku.

Cilj ovog rada je analizirati pravni okvir Europske unije koji uređuje usluge od općeg gospodarskog interesa, odnos ovog koncepta prema pravilima o slobodi kretanja, zaštiti tržišnog natjecanja i državnim potporama na unutarnjem tržištu EU-a te utvrditi poštuje li Republika Hrvatska navedeni okvir i postoje li prijepori u domaćem upravnom pravu koje je potrebno pravno razriješiti.

U drugom poglavlju analizira se pojam usluga od općeg gospodarskog interesa u pravnom okviru Europske unije te se precizira njegovo značenje u odnosu na 
druge bliske pravne koncepte. Nakon toga analizira se odnos usluga od općeg gospodarskog interesa i tržišnih pravila Europske unije. U idućem poglavlju prezentiran je skup upravnopravnih pravila kojima je navedeno područje uređeno u Republici Hrvatskoj, s naglaskom na potencijalne točke prijepora između nacionalnog i europskog pravnog uređenja. Naposljetku, prikazana su moguća rješenja spomenutih prijepora, sukladno relevantnim propisima i načelima pravnog poretka Europske unije.

\section{PRAVNI OKVIR EUROPSKE UNIJE}

\subsection{Pojmovno određenje}

Na početku ovog rada nužno je razgraničiti usluge od općeg gospodarskog interesa od drugih bliskih pojmova koji se pojavljuju u izvorima prava Europske unije. Pojam usluga od općeg gospodarskog interesa spominje se na nekoliko mjesta u primarnom pravu EU-a. Čl. 14. Ugovora o funkcioniranju Europske unije tako propisuje da, ne dovodeći u pitanje relevantne odredbe Ugovora koje uređuju pitanja nadležnosti, tržišnog natjecanja i državnih potpora, s obzirom na ulogu usluga od općeg gospodarskog interesa kao dijela zajedničkih vrijednosti Europske unije te njihovu ulogu u promicanju teritorijalne i socijalne kohezije, EU i države članice, sukladno vlastitim ovlastima u okviru područja primjene Ugovora, vode računa o tome da se navedene usluge odvijaju na temelju načela i uvjeta, osobito financijskih i gospodarskih, koji omogućuju ispunjavanje njihovih zadataka. Europski parlament i Vijeće, u redovitom zakonodavnom postupku, uredbama utvrđuju navedena načela i propisuju te uvjete, ne dovodeći u pitanje nadležnost država članica da, u skladu s pravom EU-a, naručuju, pružaju i financiraju navedene usluge. Člankom 106. Ugovora propisano je da poduzetnici kojima je povjereno obavljanje usluga od općeg gospodarskog interesa ili koje po svojoj prirodi predstavljaju monopole koji ostvaruju prihod, podliježu pravilima propisanima Ugovorima, a osobito pravilima kojima se uređuje tržišno natjecanje, u onoj mjeri u kojoj primjena spomenutih pravila ne sprečava obavljanje posebnih zadaća koje su takvim poduzećima povjerene. Pri tome se na razvoj trgovine ne smije utjecati u onoj mjeri u kojoj bi to bilo suprotno interesima EU-a. Naposljetku, treba spomenuti Protokol (br. 26) o uslugama od općeg gospodarskog interesa, kojim je određeno da zajedničke vrijednosti EU-a vezane uz usluge od općeg gospodarskog interesa osobito uključuju: bitnu ulogu i široku autonomiju lokalnih, regionalnih i nacionalnih tijela u naručivanju, pružanju i organiziranju ovih usluga koje su u najvećoj mogućoj mjeri povezane s potrebama korisnika; raznolikost tih usluga te razlike u potrebama i sklonostima korisnika koje mogu proizlaziti iz različitih kulturnih, geografskih i socijalnih okolnosti; 
visoku razinu sigurnosti, kvalitete i financijske dostupnosti, jednak tretman i promicanje univerzalnog pristupa korisnika ovim uslugama. ${ }^{1}$

Primarno pravo EU-a ne sadržava jasniju definiciju pojma usluga od općeg gospodarskog interesa, koji je iz navedenog razloga potrebno potražiti u drugim izvorima prava Unije. U tom smislu Europska komisija u svojoj Komunikaciji iz 2011. određuje da su usluge od općeg interesa one usluge za koje javna tijela država članica Unije smatraju da su od općeg interesa, iz kojeg razloga se na njih primjenjuju posebne obveze u sferi javnih usluga. Te usluge može pružati javni ili privatni sektor, a obuhvaćaju gospodarske i negospodarske usluge. ${ }^{2}$

Usluge od općeg gospodarskog interesa one su osnovne usluge koje se obavljaju sukladno pravilima o tržišnom natjecanju i unutarnjem tržištu, ali se uopće ne bi mogle obavljati (ili obavljati pod istim uvjetima u smislu sigurnosti, dostupnosti, kvalitete, univerzalnog pristupa itd.) bez intervencije javnih tijela. Dopuštena su odstupanja od tržišnih pravila ako je to nužno kako bi se zaštitio pristup građana osnovnim uslugama. ${ }^{3}$

Socijalne usluge od općeg interesa obuhvaćaju sustave socijalne sigurnosti za zaštitu ljudi od osnovnih životnih rizika (poput starosti) i temelje se na načelu

1 Vidi pročišćene verzije Ugovora o Europskoj uniji i Ugovora o funkcioniranju Europske unije, Ugovor o Europskoj uniji [2016], Službeni list br. C202/l. Osim navedenog, treba napomenuti da je člankom 36. Povelje Europske unije o temeljnim pravima [2016], Službeni list br. C202/389, propisano da, radi promicanja teritorijalne i socijalne kohezije, EU priznaje i poštuje pristup službama od općeg gospodarskog interesa kako je predviđeno zakonodavstvima i praksom država članica te u skladu s Ugovorima. Za analizu usluga od općeg gospodarskog interesa vidi, primjerice, Fiedziuk, V., Putting services of general economic interest up for tender: Reflections on applicable EU rules, Common Market Law Review, vol. 50, br. 1, 2013., str. 87 - 114; Klarić, M.; Nikolić, M., Ustrojstvo javnih službi u Europskom pravnom poretku, Zbornik radova Pravnog fakulteta u Splitu, vol. 48, br. 1, 2011 ., str. 89 - 102; Sauter, W., Services of general economic interest and universal service in EU law, TILEC Discussion Paper, 2008.; Stanković, D., Uloga postupka javne nabave u financiranju usluga od općeg gospodarskog interesa, Zagrebačka pravna revija, vol. 7, br. 1, 2018., str. 53 - 69; Van de Gronden, J., Social Services of General Interest and EU Law, u: Szyszczak, E. et al. (ur.), Developments in Services of General Interest, T.M.C. Asser Press, The Hague, 2011.

2 Vidi Communication from the Commission to the European Parliament, the Council, the European Economic and Social Committee and the Committee of the Regions - A Quality Framework for Services of General Interest in Europe COM(2011) 900 final, str. 3 - 4. Vidi također Communication from the Commission to the European Parliament, the Council, the European Economic and Social Committee and the Committee of the Regions - White Paper on services of general interest COM(2004) 374 final i Green paper on services of general interest $\operatorname{COM}(2003) 270$ final.

$3 \quad$ Ibid. 
solidarnosti. One mogu biti gospodarske ili negospodarske prirode. Te usluge, osim socijalnog osiguranja, mogu uključivati i, primjerice, socijalnu pomoć. ${ }^{4}$

Naposljetku, postoje negospodarske usluge od općeg interesa. Protokolom (br. 26) o uslugama od općeg gospodarskog interesa određeno je da Odredbe Ugovora ne utječu na nadležnost država članica za naručivanje, pružanje i organiziranje ovih usluga. Sam pojam nije definiran Protokolom, a nije izričito definiran ni od strane Europske komisije. ${ }^{5}$ Njih bi se moglo za početak odrediti na negativan način kao one usluge od općeg interesa koje nisu obuhvaćene pojmom usluga od općeg gospodarskog interesa.

Iz svega navedenog proizlaze dva bitna zaključka. Prvo, konkretno određivanje koje su to usluge od općeg gospodarskog interesa prepušteno je autonomiji država članica. Ta autonomija, međutim, nije apsolutna, već su okviri definirani pravom EU-a. Drugo, ključan faktor u smislu određivanja ovih usluga je njihova gospodarska, odnosno negospodarska priroda jer su usluge od općeg gospodarskog interesa podvrgnute tržišnim pravilima EU-a, za razliku od onih negospodarskih. Kriterijima za određivanje ove distinkcije bit će posvećeno iduće poglavlje.

\subsection{Gospodarska i negospodarska aktivnost}

Pravila o tržišnom natjecanju i državnim potporama Europske unije primjenjuju se na poduzetnike, a poduzetnici su oni subjekti koji obavljaju gospodarsku aktivnost bez obzira na njihov pravni status (primjerice, jesu li u privatnom ili državnom vlasništvu) i način financiranja. ${ }^{6}$ Ovu definiciju postavio je Sud Europske unije još 1991., primjenjujući funkcionalni pristup, pri čemu se naglasak stavlja na konkretnu djelatnost koju obavlja neki subjekt, uzimajući u obzir gospodarske okolnosti slučaja i ostale relevantne činjenice. ${ }^{7}$

4 Ibid.

5 Ibid.

6 Vidi predmet C-41/90 Klaus Höfner and Fritz Elser v Macrotron GmbH [1991] ECR I-1979. Vidi i Odudu, O., Are State-Owned Health-Care Providers Undertakings Subject to Competition Law?, European Competition Law Review, vol. 48, br. 5, 2011., str. 231 241 i Townley, C., The Concept of an 'Undertaking': The Boundaries of the Corporation - A Discussion of Agency, Employees and Subsidiaries u: Amato, G.; Ehlermann, C. (ur.), The Concept of an 'Undertaking': The Boundaries of the Corporation - A Discussion of Agency, Employees and Subsidiaries, Hart Publishing, Oxford, 2007., str. 23.

7 Vidi Cerovac, M., Pojam poduzetnika u pravu tržišnog natjecanja, Hrvatska pravna revija, br. 10, 2005., str. 60 - 70. i Poščić, A., Pojam poduzetnika u europskom pravu tržišnog natjecanja, Zbornik Pravnog fakulteta Sveučilišta u Rijeci, vol. 29, br. 2, 2008., str. 
Niz je kriterija koji se uzimaju u obzir prilikom utvrđivanja je li riječ u nekoj situaciji o gospodarskoj ili negospodarskoj djelatnosti. Iz sudske prakse proizlazi da su u tom smislu posebno važni socijalna svrha/funkcija subjekta, solidarnost, ostvarivanje dobiti i postojanje državne kontrole nad aktivnostima subjekta. ${ }^{8}$ Kriterij svrhe Sud je prvi put uzeo u obzir u predmetu Poucet i Pistre, kad je utvrdio da obvezni sustav državnog (javnog) socijalnog osiguranja ne pripada u područje primjene tržišnih pravila EU-a zbog svoje socijalne svrhe. ${ }^{9}$ Za razliku od njega, dobrovoljno životno osiguranje predstavlja gospodarsku aktivnost bez obzira na socijalnu funkciju koju ima, iz čega jasno proizlazi da je socijalna svrha/funkcija subjekta samo jedan od kriterija koji se uzimaju u obzir prilikom (ne)primjene tržišnih pravila Europske unije. ${ }^{10}$

Usko povezani s kriterijem socijalne svrhe su i ostali spomenuti faktori. Solidarnost je iznimno važna u kontekstu mirovinskog i zdravstvenog osiguranja. Kod potonjeg je posebno bitno da su davanja (doprinosi) koje osiguranici uplaćuju proporcionalni prihodu tih osoba, a ne riziku prema kojem se inače određuju premije osiguranja koja posluju po tržišnim načelima. Mirovinsko osiguranje u kojem postojeći osiguranici financiraju umirovljenike (međugeneracijska solidarnost) također ne predstavlja gospodarsku aktivnost. S druge strane, dobrovoljno mirovinsko osiguranje koje se temelji na kapitalizaciji upravo zbog svoje dobrovoljnosti kojom se ograničava primjena načela solidarnosti predstavlja gospodarsku aktivnost, bez obzira na socijalnu svrhu zbog koje je osnovano. ${ }^{11}$ Solidarnost može isključivati primjenu tržišnih pravila i na pružatelje (javnih) usluga poput zdravstvenih. U tom smislu je Sud utvrdio da bolnice koje predstavljaju dio solidarnog, besplatnog zdravstvenog sustava pretežno financiranog od strane države ne obavljaju gospodarsku djelatnost. ${ }^{12}$

917 - 939. Vidi i Obavijest Komisije o pojmu državne potpore iz članka 107. stavka 1. Ugovora o funkcioniranju Europske unije [2016] Službeni list br. C262/01 iz koje proizlazi da su kriteriji isti u kontekstu državnih potpora i prava tržišnog natjecanja.

8 Vidi Sokol, T.; Staničić, F., Pravni položaj Katoličke Crkve kao gospodarskog subjekta u pravu Europske unije i hrvatskom pravu, Zbornik Pravnog fakulteta u Zagrebu, vol. 68, br. 1, 2018., str. $31-60$.

9 Vidi spojene predmete C-159/91 i C-160/91 Christian Poucet v Assurances Générales de France and Caisse Mutuelle Régionale du Languedoc-Roussillon [1993] ECR I-637 točka 8.

10 Vidi predmet C-244/94 Fédération Française des Sociétés d'Assurance, Société Paternelle-Vie, Union des Assurances de Paris-Vie and Caisse d'Assurance et de Prévoyance Mutuelle des Agriculteurs v Ministère de l'Agriculture et de la Pêche [1995] ECR I-4013 točke 17 - 20.

11 Vidi Poucet i Pistre, op. cit., točke 10 - 11 i Fédération Française des Sociétés d'Assurance, op. cit., točka 19.

12 Vidi predmet T-319/99 Federación Nacional de Empresas de Instrumentación Científica, Médica, Técnica y Dental (FENIN) v Commission of the European Communities [2003] 
Ostvarivanje dobiti također se uzima u obzir prilikom određivanja je li riječ o gospodarskoj ili negospodarskog djelatnosti u svakom pojedinom slučaju. Izostanak ostvarivanja dobiti predstavlja jak indikator da se ne radi o gospodarskoj aktivnosti, mada ni ovaj kriterij, kao ni prethodni, nije apsolutan i primjenjiv u svim situacijama. Tako mirovinski fondovi koji sami određuju iznose davanja i doprinosa i ovise o uspješnosti vlastitih ulaganja na financijskom tržištu obavljaju gospodarsku djelatnost, iako nema namjere ostvarivanja dobiti. ${ }^{13}$

Na kraju, tu je i kriterij državne kontrole. U slučaju Freskot, u kojem je bila riječ o osiguranju poljoprivrednika od štete, iznosi davanja i doprinosa i davanja bili su određeni grčkim nacionalnim zakonodavstvom, a nadležni fond koji je isplaćivao sredstva nije imao autonomiju u određivanju bitnih elemenata osiguranja. ${ }^{14}$ Iz toga proizlazi da je postojanje državne kontrole nad djelovanjem subjekta jedan od indikatora, uz druge prije spomenute, za isključenje primjene tržišnih pravila EU-a.

Sve u svemu, ako bi se iz kazuistike sudske prakse pokušao izvući općenitiji zaključak, može se reći da države članice imaju pravo svjesno isključiti određene djelatnosti iz sfere tržišnog natjecanja. To se može napraviti bilo propisivanjem zakonskog monopola, bilo stvaranjem takvog pravnog okvira koji natjecanje s (javnim) subjektima čini posve neisplativim. S druge strane, subjekti koji se

ECR II-357 točke 35 - 44 i predmet C-205/03 P Federación Española de Empresas de Tecnología Sanitaria (FENIN) v Commission of the European Communities [2006] ECR I-6295. O toj temi vidi i, primjerice, Louri, V., The FENIN Judgment: The Notion of Undertaking and Purchasing Activity, Legal Issues of Economic Integration, vol. 32, 2005., str. 87 - 97. Treba napomenuti da stranke uopće nisu navele činjenicu da su španjolske bolnice u nekim slučajevima ipak naplaćivale privatne zdravstvene usluge koje su pružale osobama koje nisu obuhvaćene španjolskim zdravstvenim sustavom (poput stranih turista), što je moglo utjecati na odluku Suda.

13 Vidi predmet C-67/96 Albany International BV v Stichting Bedriffspensioenfonds Textielindustrie [1999] ECR I-5751 točke 81 - 86.

14 Vidi predmet C-355/00 Freskot AE v Elliniko Dimosio [2003] ECR I-5263 točke 76 - 79. Subjekti čije su sve aktivnosti povezane s njihovim specifičnim javnim ovlastima, poput kontrole zračnog prostora, također se ne smatraju poduzetnicima u kontekstu prava Europske unije. Vidi predmet C-364/92 SAT Fluggesellschaft mbH v Eurocontrol [1994] ECR I-0043 točke 19 - 31. U navedenom predmetu ključna je bila priroda same djelatnosti, čija je svrha zaštite sigurnosti zračnog prometa nužno povezana s javnom vlasti te stoga nije riječ o gospodarskoj djelatnosti na koju se primjenjuju propisi EU-a o zaštiti tržišnog natjecanja i državnim potporama. O ovoj presudi vidi i, primjerice, Svetlicinii, A., Back to the Basics: Concepts of Undertaking and Economic Activity in the Selex Judgment, European Law Reporter, vol. 12, 2009., str. $422-427$. 
pružanjem usluga na tržištu natječu s drugim subjektima i snose poslovni rizik mogu se smatrati poduzetnicima. ${ }^{15}$

U kontekstu pravila o slobodi pružanja usluga na unutarnjem tržištu situacija nije puno jasnija. U kontekstu obrazovanja Sud je utvrdio da gospodarsku aktivnost predstavljaju one usluge koje se uobičajeno pružaju uz naknadu, pri čemu potonja zapravo predstavlja ekonomsku protučinidbu za pruženu uslugu. S druge strane, uspostavljajući i održavajući javni obrazovni sustav, koji se u pravilu financira iz javnog proračuna, a ne od strane roditelja ili samih učenika, država nema namjeru obavljati djelatnosti uz naknadu, već ispunjava vlastitu zadaću koju ima prema svojem stanovništvu u obrazovnoj, socijalnoj i kulturnoj sferi. U takvim slučajevima nema gospodarske aktivnosti. ${ }^{16}$ Oni, pak, obrazovni programi koji se financiraju privatnim sredstvima koja ne potječu od pružatelja usluga predstavljaju gospodarsku aktivnost jer je cilj obrazovnih ustanova u takvom slučaju ponuditi uslugu uz određenu naknadu i ostvariti dobit (mada i subjekti koji nemaju cilj ostvariti dobit mogu obavljati gospodarsku aktivnost). ${ }^{17}$ Naravno, upitno je što se događa u situaciji u kojoj određeni programi imaju više izvora financiranja (dio iz privatnih, a dio iz javnih sredstava). Drugim riječima, i ovdje, kao u slučaju tržišnog natjecanja i državnih potpora, (ne)postojanje gospodarske aktivnosti utvrđivat će se u svakom pojedinom slučaju uzimajući u obzir niz kriterija definiranih primarno kroz praksu Suda Europske unije.

15 Vidi spojene predmete C-180/98 do C-184/98 Pavel Pavlov and Others v Stichting Pensioenfonds Medische Specialisten [2000] ECR I-6451 točka 76.

16 Vidi predmet 263/86 Belgian State v René Humbel and Marie-Thérèse Edel [1988] ECR 5365 točke 14 - 20. Vidi također i Hatzopoulos, V., Killing National Health and Insurance Systems but healing Patients? The European Market for Health Care Services after the Judgements of the ECJ in Vanbraekel and Peerbooms, Common Market Law Review, vol. 39, br. 4., 2002., str. 683 - 729. Negospodarske službe od općeg interesa isključene su i iz područja primjene Direktive 2006/123/EZ Europskog parlamenta i Vijeća od 12. prosinca 2006. o uslugama na unutarnjem tržištu [2016] Službeni list br. L376/36., sukladno njezinu čl. 2. Vidi u tom smislu i predmet C-393/17 Openbaar Ministerie v Freddy Lucien Magdalena Kirschstein and Thierry Frans Adeline Kirschstein točke $53-60$.

17 Vidi predmet C-109/92 Stephan Max Wirth v Landeshauptstadt Hannover [1993] ECR I-6447 točke 13 - 20 i C-281/06 Hans-Dieter Jundt and Hedwig Jundt v Finanzamt Offenburg [2007] ECR I-12231 točka 33. 


\subsection{Usluge od općeg gospodarskog interesa i tržišna pravila Europske unije}

Postojanje usluge od općeg gospodarskog interesa ne znači da će se na nju primijeniti tržišna pravila Europske unije bez ikakvih ograničenja. Kao što je navedeno u prethodnim poglavljima, sigurnost, dostupnost, kvaliteta i univerzalni pristup bitni su elementi prilikom uređivanja usluga od općeg gospodarskog interesa. Ako se ovi elementi ne bi mogli ostvariti bez intervencije javnih tijela, potreban je poseban pravni okvir koji omogućuje i odstupanja od tržišnih pravila ako su ona nužna za ostvarenje ciljeva takvih usluga.

Prvi slučaj koje ovdje treba spomenuti obuhvaća situaciju u kojoj tržišna pravila o (zabranjenim) državnim potporama uopće nisu primjenjiva ako su zadovoljeni sljedeći kriteriji za postojanje usluge od općeg gospodarskog interesa (predmet Altmark):

1) Poduzetniku korisniku naknade koju dobiva od javnog tijela mora doista biti povjerena obveza pružanja javne usluge, a navedene obveze pri tome moraju biti jasno definirane kako se naknada koju poduzetnik dobiva od javne vlasti ne bi smatrala državnom potporom.

2) Parametri prema kojima se izračunava spomenuta naknada moraju biti jasno unaprijed utvrđeni, na transparentan i objektivan način.

3) Visina pružene naknade ne smije prijeći onaj iznos koji je nužan za naknadu nastalih troškova uz ostvarivanje razumne dobiti poduzetnika.

4) Ako nije proveden javni natječaj za odabir poduzetnika koji će pružati navedenu uslugu, visina spomenute naknade mora biti određena na osnovi analize troškova koji bi pri izvršavanju obveza pružanja javne usluge nastali prosječnom dobro upravljanom i ekipiranom poduzetniku, uzimajući u obzir povezane prihode i razumnu dobit od izvršavanja navedenih obveza. $^{18}$

Ako su ispunjeni navedeni uvjeti, nema državne potpore, što znači da tržišna pravila EU-a u ovom području nisu primjenjiva i nema potrebe za dodatnim opravdavanjem državnih mjera koje uređuju usluge od općeg gospodarskog interesa. Iz uvjeta jasno proizlazi da država nema apsolutnu autonomiju u definiranju usluga od općeg gospodarskog interesa i njihovu izuzimanju iz po-

18 Vidi Obavijest Komisije o pojmu državne potpore iz članka 107. stavka 1. UFEU-a [2016] Službeni list br. C262/1 i predmet C-280/00 Altmark Trans GmbH and Regierungspräsidium Magdeburg v Nahverkehrsgesellschaft Altmark GmbH, and Oberbundesanwalt beim Bundesverwaltungsgericht [2003] ECR I-7747 točke 88 - 93. Vidi i Sauter, op. cit. u bilj. 1 i Klarić; Nikolić, op. cit. u bilj. 1. 
dručja primjene tržišnih pravila. Tu su posebno važni drugi i četvrti uvjet jer onemogućuju državi da proglašenjem nečega uslugom od općeg gospodarskog interesa opravda netransparentno trošenje proračunskih sredstava i neučinkovito upravljanje javnim poduzećima (bilo trgovačkim društvima, bilo ustanovama).

Primjer za isključenje pravila o zabranjenim državnim potporama može biti dopunsko zdravstveno osiguranje. Tako dobrovoljno osiguranje utemeljeno na obvezi omogućavanja slobodnog pristupa svakoj osobi, neovisno o spolu, dobi, zdravstvenom stanju; na tome da svi osiguranici plaćaju jednaku premiju za istu vrstu proizvoda, neovisno o osiguranikovu zdravstvenom stanju; pri tome oni (privatni) osiguravatelji čiji je profil rizika bolji od prosječnog tržišnog profila rizika plaćaju naknadu državnom tijelu koje plaća odgovarajući iznos onim osiguravateljima čiji je profil rizika lošiji od prosječnog tržišnog profila rizika; te kad su plaćanja ograničena na najmanju razinu koja je nužna da se osiguravateljima korisnicima naknade omogući ispunjavanje obveze pružanja usluge od općeg gospodarskog interesa, nije obuhvaćeno pravilima o državnim potporama. ${ }^{19}$

U praksi može doći do određenih nedoumica u primjeni drugog i četvrtog uvjeta u odnosu na čl. 106. Ugovora koji određuje kako postupiti u situaciji u kojoj tržišna pravila jesu primjenjiva (za razliku od Altmarka), ali otežavaju pružanje usluge od općeg gospodarskog interesa u konkretnom slučaju. Tome je posvećena daljnja analiza.

Ako su tržišna pravila ipak primjenjiva na određenu uslugu od općeg interesa, može doći do toga da njihova primjena onemogućava pružanje takvih usluga, odnosno postizanje ciljeva koji su im zadani. Drugim riječima, potrebno je balansiranje usluga od općeg gospodarskog interesa i njihovih ciljeva s jedna strane i tržišnih pravila i njihovih ciljeva s druge strane. Tu je riječ o specifičnom obliku testa proporcionalnosti. Prema sudskoj praksi, odstupanja od tržišnih pravila definiranih Ugovorima dopuštena su ako su nužna za obavljanje posebnih zadaća povjerenih poduzetniku zaduženom za pružanje usluge od općeg gospodarskog interesa. S tim u vezi, iz sudske prakse Suda (primjerice, predmet Viasat) proizlazi da nije nužno da postoji prijetnja financijskoj ravnoteži ili gospodarskoj održivosti poduzetnika kojemu je povjereno obavljanje usluge od općeg gospodarskog interesa. Dovoljno je da bi u slučaju nepostojanja spornih naknada (potpora) koje poduzetniku dodjeljuje država bilo onemogućeno obavljanje posebnih zadaća koje su tom poduzetniku povjerene ili da je zadržavanje tih naknada nužno kako bi se njihovu primatelju omogućilo obavljanje zadaća od

19 Vidi predmet T-289/03 British United Provident Association Ltd (BUPA), BUPA Insurance Ltd and BUPA Ireland Ltd v Commission of the European Communitie [2008] ECR II-008I. 
općeg gospodarskog interesa koje su mu povjerene pod gospodarski prihvatljivim uvjetima. Pri rješavanju spornih situacija nije potrebno provjeriti je li poštovanje drugog i četvrtog uvjeta iz presude Altmark spriječilo društvo koje pruža uslugu od općeg gospodarskog interesa u obavljanju zadaće koja mu je povjerena. ${ }^{20}$ Dakle, čl. 106. Ugovora može se primijeniti i dati prednost uslugama od općeg gospodarskog interesa u odnosu na tržišna pravila čak i ako poduzetnik koji pruža uslugu od općeg gospodarskog interesa ne može proći test usporedbe s tipičnim poduzetnikom, dobro vođenim i odgovarajuće opremljenim kako bi mogao ispuniti tražene zahtjeve javne usluge.

Iz navedenog, a i iz drugih presuda $S_{d a^{21}}$, proizlazi da se u slučaju usluga od općeg gospodarskog interesa i primjene čl. 106. Ugovora primjenjuje blaži oblik testa proporcionalnosti, prema kojem država ne mora dokazati da se cilj od općeg interesa ne može postići drugim sredstvima koja su manje ograničavajuća za tržište od mjere koja je u pitanju. Drugim riječima, subjekt koji tvrdi da je došlo do povrede tržišnih pravila mora dokazati da je država mogla upotrijebiti neku drugu učinkovitu mjeru koja manje ograničava tržišne slobode. U tom smislu navedeni elementi sudske prakse pokazuju da je država stavljena u dosta povoljan položaj.

Ipak, sudska praksa nije u potpunosti konzistentna. Tako je u predmetu Dusseldorp, u kojem se radilo o nizozemskom trgovačkom društvu koje je dobilo monopol na uništavanje opasnog otpada, Sud utvrdio da je nizozemska vlada morala dokazati da cilj od općeg interesa nije bilo moguće ostvariti drugim sredstvima nego dodjeljivanjem navedenog monopola. ${ }^{22}$ Iz samog obrazloženja presude, međutim, nije jasno koje su razlike između ovog i ostalih prije spomenutih predmeta koje opravdavaju različit pristup teretu dokazivanja i testu proporcionalnosti. Činjenica je da je svaki predmet koji dođe pred sud specifičan, ali određene nekonzistentnosti koje ne proizlaze nužno iz različitih okolnosti slučaja nikako nisu dobre za pravnu sigurnost u Europskoj uniji.

20 Vidi predmet C-320/91 Criminal proceedings against Paul Corbeau [1993] ECR I-2533 točke 8 - 20 i predmet C-660/15 P Viasat Broadcasting UK Ltd v European Commission točke $21-39$.

21 Vidi predmet C-157/94 Commission of the European Communities v Kingdom of the Netherlands [1997] ECR I-5699 točke 57 - 58. Vidi i Baquero Cruz, J., Beyond Competition: Services of General Interest and European Community Law u: de Burca, G., (ur.), EU Law and the Welfare State: In Search of Solidarity, Oxford University Press, Oxford, 2005., str. $169-212$.

22 Vidi predmet C-203/96 Chemische Afvalstoffen Dusseldorp BV and Others v Minister van Volkshuisvesting, Ruimtelijke Ordening en Milieubeheer [1998] ECR I-4075 točka 67. 
Na kraju ovog dijela može se zaključiti da je odnos između usluga od općeg gospodarskog interesa i tržišnih pravila EU-a vrlo kompleksan. Prvo, ako su zadovoljeni uvjeti iz predmeta Altmark, tržišna pravila uopće nisu primjenjiva i država može ovlastiti poduzetnika za pružanje usluge od općeg gospodarskog interesa i dati mu financijsku pomoć u tu svrhu. Pri tome mora biti riječ o poduzetniku kojim se upravlja na kvalitetan način, financijska pomoć je nužna za obavljanje navedene usluge, a njezin iznos je objektivno i transparentno utvrđen. Drugo, ako tržišna pravila jesu primjenjiva, odstupanje nacionalnih pravila od tržišta ipak će se moći opravdati ako je to odstupanje nužno za ostvarenje cilja od općeg interesa radi kojeg se određena usluga pruža.

\section{HRVATSKI UPRAVNOPRAVNI OKVIR I USLUGE OD OPĆEG GOSPODARSKOG INTERESA}

U ovom dijelu rada analizirat ćemo hrvatski pravni (regulatorni) okvir u nizu sektora u kojima možemo govoriti o pružanju usluga od općeg gospodarskog interesa ili u kojima dolazi do dvojbi je li riječ o usluzi od općeg gospodarskog interesa ili negospodarskoj usluzi od općeg gospodarskog interesa. Naša analiza pokazat će (ne)sukladnost našeg upravnopravnog okvira s pravom EU-a u skladu s kriterijima iz presude Altmark.

\subsection{Javni prijevoz u obalnom pomorskom prometu kao usluga od općeg gospodarskog interesa}

Javni prijevoz u obalnom pomorskom prometu uređen je $\mathrm{u}$ Republici Hrvatskoj primarno Zakonom o prijevozu u linijskom i povremenom obalnom pomorskom prometu (dalje u tekstu: ZPLPOP).$^{23}$ Nužno je napomenuti i postojanje posebnog zakona koji je od važnosti za ovaj rad, a to je Zakon o Jadroliniji, Rijeka $^{24}$ kao državnom brodaru. Riječ je o djelatnosti od javnog interesa za

23 Narodne novine, br. 33/2006, 38/2009, 87/2009, 18/2011, 80/2013, 56/2016.

24 Narodne novine, br. 11/1996, 33/2006. Na temelju ovog zakona Javno poduzeće Jadrolinija p.o. Rijeka osnovano Zakonom o osnivanju Javnog poduzeća “Jadrolinija” p.o. Rijeka (Narodne novine, br. 27/1991) preoblikovalo se u društvo s vlastitom pravnom osobnošću na koje se, ako tim Zakonom nije drukčije propisano, primjenjuju propisi koji vrijede za društva s ograničenom odgovornošću (čl. 1. st. 1. i 2.). Predmet poslovanja Društva čine djelatnosti: linijski (redovni) pomorski prijevoz putnika i tereta (čl. 1. st. 5.). 
Republiku Hrvatsku. ${ }^{25}$ Cilj ZPLPOP-a jest osiguravanje redovite povezanosti naseljenih otoka s kopnom i naseljenih otoka međusobno s primjerenim brojem dnevnih veza u oba pravca, a sve u cilju zadovoljenja potreba otočana, stvaranja boljih uvjeta za život na otocima i poticanje njihova razvitka. ${ }^{26}$ Potrebno je naglasiti da se uspostava sustava ovakvog prijevoza kao javne usluge temelji na načelima ${ }^{27}$ koja, već sama za sebe, govore o tome da je riječ o kategoriji usluge koja se obavlja na način koji nije potpuno tržišni. U skladu sa ZPLPOP-om, za obavljanje usluge javnog obalnog linijskog pomorskog prijevoza na državnim, županijskim, međužupanijskim i lokalnim linijama, koje se obavljaju temeljem koncesije, davatelj koncesije odnosno javni naručitelj ${ }^{28}$ može nametnuti obvezu javne usluge. ${ }^{29} \mathrm{U}$ tom smislu navedene su usluge usluge od općeg gospodarskog interesa, pa u skladu s tim javni naručitelj (odnosno koncedent) može dodijeliti potporu za obavljanje usluge javnog prijevoza koja je od općeg gospodarskog interesa i s obvezom javne usluge, a koja ne smije biti viša od iznosa koji je nužan za podmirenje troškova brodara nastalih zbog obavljanja obveze javne usluge

25 Mandić, N.; Amižić Jelovčić, P., Novine u Zakonu prijevozu u linijskom i povremenom obalnom pomorskom prometu iz 2013. godine, Poredbeno pomorsko pravo, vol. 53, br. 168, 2014., str. 127.

Vidi čl. 3. ZPLPOP-a.

27 To su sljedeća načela (vidi čl. 3. ZPLPOP-a):

poticanja gospodarskog razvoja otoka,

kontinuiteta i redovitosti prijevoza s brodovima određenog kapaciteta i vrste te osiguranju odgovarajuće kvalitete prijevoza,

usluga prijevoza s unaprijed određenim cijenama i drugim uvjetima, i to posebno za određene kategorije putnika i za određene linije,

davanja naknade za obavljanje javne usluge brodarima, bez koje se ne može osigurati kontinuitet i redovitost javnog prijevoza na određenim linijama,

prilagođavanja javnog prijevoza stvarnim zahtjevima,

osiguravanja dodatnih usluga prijevoza.

Za državne linije to je Agencija za obalni promet, za županijske linije to je županijska skupština, a za lokalne linije to je gradsko ili općinsko vijeće, dok je za međužupanijske linije to zajednička odluka županijskih skupština (čl. 27. ZPLPOP-a).

Linije s obavezom javne usluge su: 24 državne trajektne linije (samo liniju Mišnjak - Stinica ne održava Jadrolinija nego Rapska plovidba, dakle državni brodar održava 23 od 24 državne trajektne linije), 12 državnih brodskih linija (državni brodar održava četiri linije, ostalih osam održavaju privatni brodari) te 15 državnih brzobrodskih linija (državni brodar održava sedam linija, a ostalih osam održavaju privatni brodari). Prema tome, od ukupno 51 državne linije državni brodar Jadrolinija održava ukupno njih 34, odnosno 66 \% (dvije trećine). Dostupno na: https:// agencija-zolpp.hr/linije/ (18. studenog 2019.). 
prijevoza, uzimajući u obzir ostvarene prihode, kao i razumnu dobit. ${ }^{30}$ Treba napomenuti da je ZPLPOP izmijenjen 2013. godine kako bi se sustav prilagodio načelima sadržanima u Uredbi (EEZ) broj 3577/92 od 7. prosinca 1992. godine o primjeni načela slobode pružanja usluga u pomorskom prijevozu unutar država članica (pomorska kabotaža) ${ }^{31}$ te s Uredbom (EU) broj 1177/2010 od 24. studenoga 2010. godine o pravima putnika prilikom putovanja morem i unutarnjim plovnim putovima, kojom se mijenja Uredba (EZ) broj 2006/200424 (dalje u tekstu: Uredba (EU) broj 1177/2010). ${ }^{32}$ U sklopu navedenih izmjena Vlada Republike Hrvatske donijela je i Uredbu o uvjetima i vrednovanju kriterija za davanje koncesije i sklapanje ugovora o javnoj usluzi za obavljanje javnog prijevoza u linijskom obalnom pomorskom prometu. ${ }^{33}$ Tom su Uredbom propisani uvjeti za davanje koncesije i za sklapanje ugovora o javnoj usluzi za obavljanje javnog prijevoza u linijskom obalnom pomorskom prometu, vrednovanje kriterija za davanje koncesije i za sklapanje ugovora o javnoj usluzi, kriteriji za određivanje cijene usluga i davanje naknade za obavljanje javne usluge, visinu i način plaćanja naknade za koncesiju, vrstu i vrijednost jamstva za ozbiljnost ponude i druga pitanja koja se odnose na postupak davanja koncesije i na sklapanje ugovora o javnoj usluzi (čl. 1.). Navedena Uredba propisuje kriterije za davanje naknade za obavljanje javne usluge na linijama ispod i iznad praga od 300.000 putnika. Ako je riječ o linijama na kojima prosječni godišnji promet $\mathrm{u}$ dvije godine koje prethode godini u kojoj je povjereno obavljanje usluge od općeg gospodarskog interesa ne prelazi 300.000 putnika, izravno se primjenjuju odredbe Odluke Komisije 2012/21/EU od 20. prosinca 2011. o primjeni članka 106. stavka 2. Ugovora o funkcioniranju Europske unije u odnosu na državne potpore u obliku naknade za pružanje javnih usluga koje se dodjeljuju određenim poduzetnicima kojima je povjereno obavljanje usluga od općeg gospodarskog interesa. ${ }^{34}$ Ako je riječ o linijama na kojima prosječni godišnji promet u dvije godine koje prethode godini u kojoj je povjereno obavljanje usluge od općeg gospodarskog interesa prelazi 300.000 putnika, naknada za obavljanje javne usluge predstavlja državnu potporu koja nije obuhvaćena citiranom Odlukom Komisije, nego se primjenjuju načela utvrđena u Priopćenju Komisije - Okvir Europske unije o državnim potporama u obliku naknade za javne usluge. ${ }^{35}$ Ipak,

30 Vidi čl. 4. t. 8. u vezi s t. 10. istog čl. ZPLPOP-a.

31 Službeni list Europske unije, br. L 364 od 12. prosinca 1992.

32 Službeni list Europske unije, br. L 334 od 17. prosinca 2010.

33 Narodne novine, br. 31/2014.

34 Službeni list Europske unije, br. L 7 od 11. siječnja 2012. godine.

35 Službeni list Europske unije, br. C 8 od 11. siječnja 2012. godine. 
propisano je da takve naknade ne predstavljaju državne potpore u smislu čl. 107. UFEU-a pod sljedećim uvjetima: brodar primatelj naknade mora uistinu imati obvezu obavljanja javnih usluga, a te obveze moraju biti jasno utvrđene, parametri na temelju kojih se naknada izračunava moraju biti doneseni unaprijed, na objektivan i transparentan način, naknada ne može prelaziti iznos koji je nužan za pokrivanje svih ili dijela troškova pretrpljenih $\mathrm{u}$ ispunjavanju obveze javnih usluga, uzimajući u obzir mjerodavne primitke i razumnu dobit, odnosno razina naknade mora biti utvrđena na temelju analize troškova koje bi tipični poduzetnik s dobrim upravljanjem i primjerenim sredstvima prijevoza, koja mu omogućuju zadovoljavanje uvjeta potrebnih za obavljanje javnih usluga, pretrpio pri ispunjenju tih obveza, uzimajući u obzir mjerodavne primitke i razumnu dobit od ispunjenja obveza (vidi čl. 39. Uredbe). Slijedom obveza Republike Hrvatske prema pravu EU-a, Uredba detaljno propisuje, ponajprije, da iznos naknade za obavljanje javne usluge ne smije premašiti nužan iznos koji je potreban za pokriće neto troškova ispunjenja obveze obavljanja javne usluge, uključujući razumnu ${ }^{36}$ dobit. Propisane su i metodologije za izračun neto troškova (NAC, čl. 43.), metodologija za razvrstavanje troškova (čl. 44.) te obveza javnog naručitelja da osigura transparentnost dodjele naknade, kao i da brodari ne prime naknadu koja premašuje iznos koji je utvrđen sukladno uvjetima navedenima Priopćenjem i Uredbom te na zahtjev Komisije dostaviti dokaze (čl. 46.). Sustav je normativno postavljen na način koji bi trebao osigurati transparentnost ${ }^{37} \mathrm{i}$ isplatu isključivo iznosa koji su potrebni za podmirivanje razlike između rashoda i prihoda na liniji uključujući razumnu dobit koji se dodjeljuje kao potpora (vidi čl. 48. st. 2. Uredbe).

Zaključno, usporedimo li naše zakonodavno uređenje na ovom području, može se zaključiti da su ispunjeni svi ${ }^{38}$ uvjeti iz presude Altmark, odnosno da se ne primjenjuju čl. 107. i 108. UFEU-a. Naime, brodarima je uistinu povjerena obveza pružanja javne usluge, pri čemu je jasno definirana obveza brodara (održavanje linije), izračun naknade je jasno određen u Uredbi koja je javno

36 Razumna dobit je stopa prinosa na kapital koju bi za čitavog razdoblja trajanja akta o ovlaštenju zahtijevao tipičan poduzetnik odnosno brodar koji bi obavljao uslugu od općeg gospodarskog interesa, uzimajući u obzir pripadajući rizik.

37 Na kraju poslovne godine brodar dostavlja financijska izvješća za svaku liniju pojedinačno po principu odvojenog knjigovodstva. Javni naručitelj obvezan je izvršiti računovodstvenu kontrolu kojom se utvrđuju konačni stvarni troškovi i prihodi linije na kraju svake poslovne godine. Brodar dostavlja financijsko izvješće linije (Račun dobiti i gubitka linije) javnom naručitelju najkasnije do 15. travnja tekuće godine za proteklu godinu.

38 Četvrti kriterij iz presude Altmark zadovoljen je jer se u svim postupcima provodi javni natječaj, nap. a. 
objavljena i svima dostupna te je način njezina određivanja takav da se osigurava da ona predstavlja onaj iznos koji je nužan za naknadu nastalih troškova uz ostvarivanje razumne dobiti poduzetnika.

\section{2. Željeznički prijevoz kao usluga od općeg gospodarskog interesa}

Željeznička infrastruktura je od interesa za RH. Na temelju priprema RH za pristupanje EU-u u željezničkom sektoru izvršene su brojne promjene. Tako je donesen Zakon o podjeli trgovačkog društva HŽ - Hrvatske željeznice d.o.o. ${ }^{39}$ na četiri trgovačka društva, s izuzimanjem željezničke infrastrukture kao javnog dobra u općoj uporabi u vlasništvu RH. Odlukom Vlade Republike Hrvatske od 20. srpnja 2006. godine osnivaju se sljedeća trgovačka društva: HŽ Infrastruktura d.o.o., HŽ Putnički prijevoz d.o.o., HŽ Cargo d.o.o. i HŽ Vuča vlakova d.o.o. te se osniva krovno društvo HŽ-Holding d.o.o., koji je u vlasništvu RH i vlasnik je spomenutih četiriju trgovačkih društava. Naknadno je HŽ-Holding d.o.o. pripojen HŽ infrastrukturi d.o.o., a HŽ Vuča vlakova d.o.o. prestajala je postojati i podijeljena je na HŽ Putnički prijevoz d.o.o. i HŽ Cargo d.o.o.

Prema našem Zakonu o željeznicama (dalje u tekstu: ZŽ $)^{40}$ moguće je upravitelju željezničke infrastrukture davati poticaje. Naime, upravljanje željezničkom infrastrukturom djelatnost je od javnog interesa (čl. 46. st. I. ZŽ-a). Navedeni poticaji daju se u okviru ugovora o upravljanju željezničkom infrastrukturom ili putem drugih regulatornih mjera ili kombinacijom poticaja za smanjenje troškova pristupa infrastrukturi u okviru ugovora o upravljanju željezničkom infrastrukturom i regulatornih mjera za smanjenje visine naknada. Međutim, kad pogledamo stanje prihoda HŽ Infrastrukture d.o.o. u 2018. godini, vidjet ćemo da je to društvo 73,5 \% svih prihoda ostvarilo iz državnog proračuna

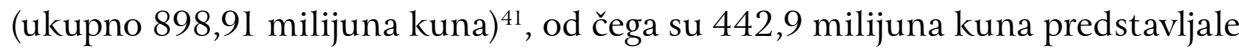
subvencije, a 481,856 milijuna kuna predstavljala su sredstva iz proračuna namijenjena društvu, dok su iz proračuna doznačena još 164,51 milijuna kuna, koje su namijenjene investicijama. ${ }^{42}$ Iz podatka da ostali prihodi društva čine samo 10,8 \% prihoda društva jasno je da bez državnih subvencija i sredstava iz proračuna društvo ne bi moglo ostvariti svoju funkciju - upravljanje željezničkom

39 Narodne novine, br. 153/2002 i 57/2012.

40 Narodne novine, br. 32/2019. Vidi čl. 8. st. 1.

41 HŽ Infrastruktura d.o.o., Godišnje izvješće 2018., dostupno na: http://www.hzinfra.hr/wp-content/uploads/2019/07/Godisnje-izvjesce-HZI-2018.pdf (21. studenog 2019.).

42 Ibid., str. 101 i 102. 
infrastrukturom, organiziranje i reguliranje željezničkog prometa, održavanje željezničke infrastrukture i provedbu investicija u željezničku infrastrukturu. Budući da je riječ o djelatnostima od interesa za RH i ne možemo govoriti o tržištu na ovom području, navedeni poticaji i sredstva iz državnog proračuna ne smatraju se državnim potporama. Naime, Europska komisija je u svojim dokumentima istaknula da se ne smatraju državnim potporama sredstva koja se daju za financiranje infrastrukture ako su zadovoljena tri uvjeta: nema direktne konkurencije, u sektoru je privatno financiranje beznačajno, infrastruktura nije namijenjena određenom pothvatu ili sektoru nego ostvaruje korist za cijelo društvo. ${ }^{43}$ Dodatno, riječ je o obavljanju usluge koje je povjereno zakonom. ${ }^{44}$

U skladu s Uredbom (EZ) br. 1370/2007 Europskog parlamenta i Vijeća od 23. listopada 2007. o uslugama javnog željezničkog i cestovnog prijevoza putnika i stavljanju izvan snage uredaba Vijeća (EEZ) br. 1191/69 i (EEZ) br. 1107/7045 treba pojasniti pojmove "javni prijevoz putnika", koji znači usluge prijevoza putnika od općeg gospodarskog interesa dostupne javnosti na nediskriminirajućoj i stalnoj osnovi te "naknada za javnu uslugu" koji označava svaku korist, posebno financijsku, koju nadležno tijelo dodijeli izravno ili neizravno iz javnih sredstava tijekom razdoblja provedbe obveze obavljanja javne usluge ili u vezi s tim razdobljem. Prema tome, moguće je, prema pravu EU-a, dodijeliti operateru javne usluge naknadu koja mora biti takva da su parametri za njezino plaćanje unaprijed utvrđeni na objektivan i transparentan način kako bi se spriječila prekomjerna naknada, odnosno plaćanje naknade ne smije premašiti iznos potreban za pokrivanje neto financijskog učinka troškova koji su nastali i prihoda koji su ostvareni ispunjavanjem obveza obavljanja javnih usluga, uzimajući u obzir odnosni prihod zadržan kod operatera javnih usluga i njegovu razumnu dobit. ${ }^{46}$ Ako je naknada za javnu uslugu obavljanja javnog prijevoza putnika ili za poštovanje tarifnih obveza ustanovljenih općim pravilima, koja je plaćena u skladu s ovom Uredbom, sukladna je sa zajedničkim tržištem. ${ }^{47} \mathrm{EU}$ je, u cilju stvaranja zajedničkog željezničkog tržišta, izradio četvrti željeznički paket ${ }^{48}$ kojemu je cilj

43 Bruzzone, G.; Moccaccio M., Infrastructure Financing and State Aid Control: The Potential for a Virtuous Relationship u: Nascimbene, B.; Di Pascale, A. (ur.), The Modernisation of State Aid for Economic and Social Development, Springer, Cham, 2018., str. 131.

Stanković, op. cit. u bilj. 1, str. 63.

45 Službeni list EU, br. L 315/1 od 2. listopada 2007.

46 Vidi čl. 4. st. 1. b) Uredbe.

47 Vidi čl. 9. st. 1. Uredbe.

$48 \mathrm{O}$ četvrtom željezničkom paketu vidi više u: Delač, Ž., Priprema i provedba četvrtoga željezničkog paketa, Željeznice, vol. 16, br. 3, 2017., str. 23 - 29. 
"postupno i nezaustavljivo stvoriti jedinstveni europski željeznički prostor." Hrvatsko zakonodavstvo, glede usluge javnog željezničkog prijevoza putnika, propisuje ponajprije da se, u skladu sa ZŽ-om, pružanje usluga željezničkog prijevoza i upravljanje željezničkom infrastrukturom temelji na načelu razdvajanja. Dodatno, o pružanju usluge u javnom željezničkom prijevozu putnika sklapa se ugovor o javnim uslugama za usluge od općeg gospodarskog interesa u javnom željezničkom prijevozu (čl. 74. st. 1. ZŽ-a). Predmet toga ugovora je pružanje te usluge i ugovorna naknada za obavljanje usluge od općeg gospodarskog interesa, koja ne smije premašiti iznos koji je nužan za pokriće neto troškova koji su nastali pri izvršenju obveze javne usluge, uzimajući u obzir prihode i razumnu dobit. ${ }^{50}$ Prema tome, hrvatski pravni okvir glede pružanja ove usluge željezničkog prijevoza usklađen je s relevantnim pravom EU-a.

\subsection{Zdravstvo kao usluga od općeg gospodarskog interesa}

Zdravstvo je područje koje postavlja niz pitanja glede prava državnih potpora i politike kako bi se ekonomska pravila EU-a trebala primjenjivati na njega. ${ }^{51}$ Pitanje koje se postavlja u pravu EU-a jest je li kod zdravstva riječ o negospodarskoj usluzi koja je onda zaštićena od tržišnog natjecanja i njegovih pravila ili je riječ o posebnom obliku usluge od općeg interesa ili usluge od općeg gospodarskog interesa ili se pak radi o komercijalnoj aktivnosti kod koje bi državne intervencije mogle spriječiti tržište od funkcioniranja ili ga poremetiti. ${ }^{52}$ Ipak, najčešće se zdravstvo, uz socijalnu skrb, naziva socijalnom uslugom od općeg interesa, čiji je glavni element da igra ključnu ulogu u organizaciji socijalnih politika u cijelom EU-u. ${ }^{53}$ Te usluge mogu

49 Ibid., str. 29.

50 Ugovor mora najmanje sadržavati:

1. opseg usluge s opisom linija i vlakova

2. obračunski izračun

3. sustav kazni za neispunjenje ugovora

4. specifikaciju vozila u uporabi

5. marketing

6. strukturu izvješća o ključnim pokazateljima i

7. program poticanja rasta prihoda.

51 Szyszczak, E., Services of General Economic Interest u: Nascimbene, B.; Di Pascale, A. (ur.), The Modernisation of State Aid for Economic and Social Development, Springer, Cham, 2018., str. 107.

52 Ibid., str. 108.

53 Gallo, D., State Aids, Social Services and Healthcare in EU Law u: Nascimbene, B.; Di Pascale, A. (ur.), The Modernisation of State Aid for Economic and Social Development, Springer, Cham, 2018., str. 267. 
biti gospodarske ili negospodarske prema svojoj prirodi ovisno o regulatornom okviru države članice. ${ }^{54} \mathrm{U}$ ocjeni je li usluga gospodarske ili negospodarske prirode ključno je, prema praksi Suda, postojanje tržišta i naplate usluga koje se pružaju. ${ }^{55}$ Praksa Suda, kao i Općeg suda, oslonila se na nekoliko kriterija koji karakteriziraju neku aktivnost kao solidarnu i prema tome negospodarsku: obvezno članstvo u socijalnom osiguranju, isključivo socijalna svrha, koristi nepovezane s iznosom doprinosa, neprofitni karakter, nepovezanost koristi i primanja osigurane osobe i nadzor od strane države. ${ }^{56} \mathrm{U}$ osnovi, ono što čini uslugu gospodarskom ili negospodarskom jest način na koji javna vlast (država članica) regulira neku aktivnost. ${ }^{57}$

U skladu s navedenim, promotrimo uređenje ovog područja u RH. Ponajprije, relevantan je Zakon o obveznom zdravstvenom osiguranju (dalje u tekstu: ZO$\mathrm{ZO}) .^{58}$ Riječ je o sustavu koji provodi Hrvatski zavod za zdravstveno osiguranje i putem kojega se svim osiguranim osobama osiguravaju prava i obveze iz obveznoga zdravstvenog osiguranja na načelima uzajamnosti, solidarnosti i jednakosti (čl. 3. st. 2. ZOZO-a). Sve osobe s prebivalištem u RH i stranci s odobrenim stalnim boravkom u RH dužni su se osigurati na obvezno zdravstveno osiguranje, kao i državljani drugih država članica Europske unije te državljani treće države s odobrenim privremenim boravkom u RH, na temelju radnog odnosa kod poslodavca sa sjedištem u RH, odnosno na temelju obavljanja gospodarske, odnosno profesionalne djelatnosti u RH (čl. 4. st. l. u vezi s čl. 5. ZOZO-a). Iz navedenoga jasno je vidljivo da je kod obveznog zdravstvenog osiguranja, kod kojega uopće nema tržišta, riječ o negospodarskoj usluzi od općeg interesa koja ne potpada pod primjenu prava EU-a.

$\mathrm{S}$ druge strane, ako promotrimo Zakon o dobrovoljnom zdravstvenom osiguranju (dalje u tekstu: ZDZO) ${ }^{59}$, vidjet ćemo da se dobrovoljno osiguranje sastoji od dopunskog zdravstvenog osiguranja, dodatnog i privatnog zdravstvenog osiguranja (čl. 2. ZDZO-a). Dobrovoljno zdravstveno osiguranje provodi društvo za osiguranje koje je dobilo dozvolu za obavljanje te vrste osiguranja od nadzornog tijela za obavljanje poslova osiguranja sukladno Zakonu o osiguranju, a iznimno od ove odredbe uslugu dopunskog i dodatnog zdravstvenog osiguranja provodi i Hrvatski zavod za zdravstveno osiguranje (čl. 8. u vezi s

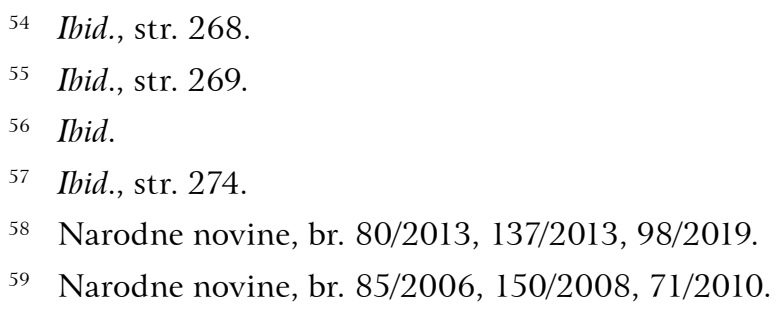


čl. 10. i 10.a ZDZO-a). Jasno je da je u ovom slučaju riječ o gospodarskoj usluzi od općeg gospodarskog interesa, da postoji tržište i da se primjenjuju pravila EU-a o zaštiti tržišnog natjecanja i o državnim potporama.

Što se tiče organizacijskih oblika pružanja zdravstvene zaštite i mogućeg postojanja tržišnog natjecanja između zdravstvenih ustanova, relevantan nam je Zakon o zdravstvenoj zaštiti (dalje u tekstu: ZZZ) ${ }^{60}$, koji propisuje tko je ovlašten osnovati zdravstvenu ustanovu. Postoje sljedeće zdravstvene ustanove: državni zdravstveni zavod, klinika, klinička bolnica i klinički bolnički centar (može ih osnovati isključivo RH), opća bolnica (može je osnovati isključivo županija ili Grad Zagreb), specijalna bolnica (može je osnovati županija, Grad Zagreb, općina ili grad te druge pravne ili fizičke osobe), dom zdravlja, zavod za hitnu medicinu i zavod za javno zdravstvo (može ih osnovati samo županija ili Grad Zagreb), poliklinika, lječilište, ustanova za zdravstvenu njegu, ustanova za palijativnu skrb, ljekarnička ustanova (mogu ih osnovati županija, Grad Zagreb i druge pravne i fizičke osobe), ustanova za zdravstvenu skrb (mogu ih osnovati samo fizičke osobe određene stručne spreme). ${ }^{61}$ Dodatno, $\mathrm{RH}$ u skladu sa ZZZ-om osigurava sredstva za investicijsko ulaganje i investicijsko i tekuće održavanje zdravstvenih ustanova kojima je osnivač, kao i za pokriće njihovih gubitaka (čl. 10. st. 2.). Prema tome, $Z Z Z$ omogućava privatnim fizičkim i pravnim osobama osnivanje samo nekih zdravstvenih ustanova, odnosno onemogućava postojanje nekih privatnih zdravstvenih ustanova. Iz toga proizlazi da određene tipove zdravstvene zaštite mogu pružati isključivo javne zdravstvene ustanove, koje su u cijelosti financirane iz javnih izvora. U tom pogledu ne postoji tržište, odnosno ne možemo govoriti o poduzetnicima. S druge strane, određene zdravstvene usluge mogu pružati, na jednak način, i javne i privatne zdravstvene osobe. Postoji li onda, u tom dijelu, tržište pružanja zdravstvenih usluga i primjenjuju li se pravila EU-a o državnim potporama i tržišnom natjecanju? Unatoč činjenici da se danas u EU-u vodi dugotrajna rasprava o pravnoj naravi zdravstvenih usluga, odnosno je li riječ o negospodarskim ili gospodarskim uslugama od općeg interesa, smatramo da se kod zdravstvene zaštite (pružanja zdravstvenih usluga) uvijek radi o negospodarskoj usluzi od općeg interesa, kada je pruža država (u širem smislu riječi, pa tu uključujemo sve zdravstvene usluge koje pružaju javno financirane $^{62}$ zdravstvene ustanove). Naime, država te usluge pruža, kako je definirano i ZZZ-om, radi očuvanja i poboljšanja zdravlja stanovništva, odnosno kao svoju socijalnu funkciju te svoje usluge u pravilu ne naplaćuje. Odnosno,

60 Narodne novine, br. 100/2018.

61 Vidi čl. 70. st. 1. - 6. ZZZ-a.

62 O tome vidi Kovač, N., Financiranje zdravstva - situacija u Hrvatskoj, Ekonomski vjesnik, vol. 26, br. 2, 2013., str. $551-563$. 
postoji obveza pružanja usluge, bez obzira na mogućnost korisnika da uslugu plati. ${ }^{63} \mathrm{~S}$ druge strane, kada govorimo o privatnim zdravstvenim ustanovama, koje svoju uslugu pružaju na tržištu i naplatno, smatramo da se može govoriti o poduzetniku u smislu prava EU-a, pa bi morala vrijediti i pravila tržišnog natjecanja, te o državnim potporama. Međutim, u skladu sa ZZZ-om, moguće je, na temelju ugovora koji se sklapa između županije odnosno Grada Zagreba ili općine i grada odnosno turističke zajednice i zdravstvene ustanove, trgovačkog društva koje obavlja zdravstvenu djelatnost ili privatnoga zdravstvenog radnika urediti organiziranje i financiranje provođenja mjera zdravstvene zaštite za povećani broj korisnika zdravstvene zaštite koje se pružaju turistima (čl. 11. st. 6.). ZZZ ne propisuje obvezu provođenja javnog natječaja za sklapanje ovakvog ugovora, niti sadržava mjere koje bi osigurale da se na ovaj način ne isplaćuju iznosi koji ne odgovaraju nužnima, odnosno može se zaključiti da se na ovakav način ne osigurava ispunjenje Altmark kriterija i da bi se moglo govoriti o prikrivenim državnim potporama.

Može se i kod nas, kao što se postavilo u Njemačkoj ${ }^{64}$, postaviti pitanje predstavljaju li neograničena jamstva za gubitak javnih zdravstvenih ustanova (za njih po zakonu jamči osnivač) državne potpore na koje bi se primijenio čl. 107. UFEU-a. U navedenim slučajevima EK je zaključio da činjenica što javna vlast jamči za obveze javne zdravstvene ustanove, a to ne vrijedi za privatne zdravstvene ustanove, ne predstavlja državnu potporu jer javna zdravstvena ustanova mora djelovati u svim okolnostima, što privatna zdravstvena ustanova ne mora. Prema tome, u slučaju pružanja sveobuhvatne zdravstvene zaštite koja uključuje i hitnu zdravstvenu zaštitu nedvojbeno je riječ o usluzi od općeg interesa koja je negospodarska. Budući da je hrvatski sustav jednak njemačkom u tom pogledu, naše zakonodavno uređenje u skladu je s pravom EU-a.

63 Vidi tako Commission Decision (EU) on State Aid 19864 - 2014/C (ex 2009/ NN54) implemented by Belgium, Public financing of Brussels public IRIS hospitals, C(2016) 4051 final.

64 Predmet T-167/04 Asklepios Kliniken GmbH v Commission of the European Communities [2007] ECR II-2379i Commission Decision (EU) concerning SA.36798 (2016/NN) - Germany - Alleged unlawful State aid for Klinikum Osnabrück GmbH, C(2016) 6689 final. 


\subsection{Univerzalna poštanska usluga kao usluga od općeg gospodarskog interesa}

Pružanje poštanskih usluga, odnosno tržište poštanskih usluga, ima važnu ulogu u gospodarskom i društvenom razvoju mnogih država. ${ }^{65}$ Danas su na tome tržištu ključni igrači nacionalni poštanski operatori i privatni operatori ${ }^{66}$ Nacionalno zakonodavstvo kojim se regulira poštansko tržište u RH u potpunosti je usklađeno s direktivama Europske unije i liberalizirano, čime su uspostavljeni jedinstveni uvjeti i načini funkcioniranja za sve sudionike. ${ }^{67}$ U pravu EU-a prihvaćeno je da, primjerice, pružanje univerzalne poštanske usluge pripada u opće usluge od gospodarskog interesa, ali kod kojih država ima mogućnost davanja subvencija, dakako, ako zadovoljavaju Altmark kriterije. Tako je u slučaju Grčke pošte ${ }^{68}$ EK potvrdio da grčke vlasti nisu previše dotirale navedeno društvo kada su podmirivale neto trošak pružanja usluge, uključujući i troškove nove moderne infrastrukture. ${ }^{69}$

Hrvatsko tržište poštanskih usluga regulirano je Zakonom o poštanskim uslugama (dalje u tekstu: ZPU) ${ }^{70}$, koji propisuje da poštanske usluge obuhvaćaju univerzalnu uslugu, zamjenske poštanske usluge i ostale poštanske usluge (čl. 14.). Dodatno, ZPU propisuje i da je obavljanje univerzalne usluge od interesa za RH (čl. 3. st. 1.) te da se korisnicima poštanskih usluga na cijelom području Republike Hrvatske mora osigurati univerzalna usluga pod jednakim uvjetima. Davatelj univerzalne usluge može prekinuti obavljanje tih usluga samo u slučaju više sile (čl. 3. st. 2.). Važno je naglasiti da je davatelj univerzalne usluge obvezan uspostaviti, održavati i razvijati poštansku mrežu na način da osigura obavljanje univerzalne usluge na cijelom području $\mathrm{RH}^{71}$ Dodatno, dužan je osigurati produženo cjelodnevno radno vrijeme (7.00 - 24.00 sata) svaki dan u tjednu u jednom poštanskom uredu na području glavnog grada, cjelodnevno radno vrijeme (npr. $8.00-20.00$ sati) u pravilu u gradovima itd.

65 Naletina, D.; Vuletić, A.; Meštrović, L., Analiza poštanskog tržišta u Republici Hrvatskoj, Zbornik Veleučilišta u Rijeci, vol. 7, br. 1, 2019., str. 301.

66 Ibid., str. 302.

67 Ibid., str. 304.

68 Hellenic (Greek) Post - ELTA.

69 Vidi Commission Decision on state aid SA.32562 - Greece - Aid to Hellenic Post, OJ C 99, 3. travnja 2012.

70 Narodne novine, br. 144/2012, 153/2013, 78/2015 i 110/2019.

71 Vidi čl. 10. st. 4. Pravilnika o obavljanju univerzalne usluge, Narodne novine, br. $41 / 2013$. 
Na tržištu poštanskih usluga u RH trenutačno djeluju 22 davatelja poštanskih usluga, od kojih jedino HP - Hrvatska pošta d.d. ima pravo na davanje univerzalne usluge. ${ }^{72} \mathrm{U}$ skladu sa ZPU-om, Hrvatska regulatorna agencija za mrežne djelatnosti (dalje u tekstu: HAKOM) određuje davatelja univerzalne usluge odlukom donesenom na temelju analize stanja tržišta poštanskih usluga u RH po načelima objektivnosti, transparentnosti i nediskriminacije, o čemu obavještava EK i nadležne regulatore u EU-u (čl. 21.). Ipak, HAKOM može odabrati pružatelja univerzalne usluge i bez javnog natječaja, ali samo ako na temelju analize stanja tržišta procijeni da samo jedan davatelj poštanskih usluga može osigurati univerzalnu uslugu na način i uz uvjete propisane ZPU-om, o čemu mora provesti javnu raspravu u trajanju od najmanje 30 dana (čl. 22. ZPU-a). S druge strane, javni natječaj je obvezan ako barem dva davatelja poštanskih usluga mogu osigurati obavljanje univerzalne usluge. Tada se javni natječaj objavljuje u Narodnim novinama i na mrežnim stranicama HAKOM-a. Na temelju natječaja odabire se pružatelj univerzalne usluge na rok koji ne može biti kraći od pet godina ni duži od 15 godina. ${ }^{73}$ Nadalje, cijene univerzalne usluge moraju biti jednake za istovrsne usluge za pismovne pošiljke za sve korisnike poštanskih usluga na cijelom području RH, pristupačne, troškovno usmjerene i poticajne za djelotvorno obavljanje univerzalne usluge te nediskriminirajuće i transparentne. Budući da je obavljanje univerzalne usluge često neisplativo, ZPU predviđa mogućnost naknade utvrđenoga nepravednog financijskog opterećenja ako njezino obavljanje stvara neto trošak. ${ }^{74}$ Tada HAKOM odlukom utvrđuje iznos neto troška koji predstavlja nepravedno opterećenje, a na zahtjev davatelja univerzalne usluge (čl. 48. st. 3. u vezi s čl. 49. st. 1. ZPU-a) te se utvrđeni iznos isplaćuje iz državnog proračuna. Davatelj univerzalne usluge dužan je uz zahtjev priložiti i detaljno obrazloženje neto troška. ${ }^{75}$ Sastavni dijelovi neto troška propisani su

72 Naletina; Vuletić; Meštrović, op. cit. u bilj. 65, str. 306.

73 Prigodom određivanja roka HAKOM mora voditi računa o tome da davatelj univerzalne usluge može osigurati povrat ulaganja (čl. 26. st. 2. ZPU-a).

74 Neto trošak je svaki trošak koji je nužan za obavljanje univerzalne usluge te je s tom uslugom povezan, a izračunava se kao razlika između neto troška davatelja univerzalne usluge koji posluje s obvezom obavljanja univerzalne usluge i neto troška koji bi davatelj univerzalne usluge imao da nema obvezu obavljanja univerzalne usluge.

75 U svrhu izračuna neto troška davatelj univerzalne usluge, koji ima obvezu obavljanja univerzalne usluge, mora izraditi prikaz poslovanja s obvezom i prikaz poslovanja bez obveze obavljanja univerzalne usluge (čl. 50. st. 1. ZPU-a), pri čemu se uzima u obzir niz zakonom propisanih parametara (npr. neto trošak temelji se samo na troškovima povezanima s obavljanjem univerzalne usluge propisane kakvoće, smanjuje se neto trošak univerzalne usluge za sve materijalne i nematerijalne koristi koje davatelj univerzalne usluge ima na temelju obavljanja univerzalne usluge itd.). 
Pravilnikom o obavljanju univerzalne usluge (čl. 21.) i njegov izračun mora se temeljiti na troškovima koji se mogu pripisati elementima univerzalne usluge koji se mogu ispunjavati samo s gubitkom ili u uvjetima u kojima troškovi nisu u skladu s uobičajenim pravilima tržišnog poslovanja. Dodatno, davatelj univerzalne usluge mora računovodstveno razdvajati prihode i troškove ostvarene od univerzalne usluge, odvojeno od prihoda i troškova ostvarenih od zamjenskih poštanskih usluga te odvojeno od prihoda i troškova ostvarenih od ostalih poštanskih usluga, po vrstama usluga i proizvodima. Takvo računovodstveno razdvajanje na temelju dosljedno primijenjenih i objektivno utemeljenih načela troškovnog računovodstva služi i kao izvor podataka za izračun neto troška univerzalne usluge (čl. 47. st. 2. ZPU-a). Kada zakonodavni okvir usporedimo s Altmark kriterijima, vidimo da je uistinu riječ o javnoj usluzi (usluga je od interesa za RH); da su parametri za izračun neto troška unaprijed utvrđeni te javno objavljeni na transparentan i objektivan način te da su parametri sastavljeni tako da se pokrivaju samo oni troškovi koji su povezani s obavljanjem univerzalne usluge kada je neizbježan gubitak odnosno kada troškovi nisu u skladu s uobičajenim pravilima tržišnog natjecanja. Javni natječaj trebao bi biti pravilo, ali i u slučaju kada se on ne provodi (ima samo jedan pružatelj koji je u stanju obavljati univerzalnu uslugu), naknada zadovoljava četvrti Altmark kriterij. Prema tome, i u ovom području hrvatski upravnopravni okvir u skladu je s pravom EU-a.

\subsection{Obrazovanje kao usluga od općeg gospodarskog interesa}

Ponajprije, valja naglasiti kako obrazovanje načelno ne potpada pod primjenu prava EU-a. Naime, UFEU ne daje izravne nadležnosti EU-u u području (visokog) obrazovanja. Ipak, Sud je legitimizirao pravo EU-a da intervenira u to područje kako bi se ostvario cilj zajedničkog tržišta. Prvi slučaj u kojemu je to Sud učinio bio je Casagrande ${ }^{76}$ i zaključak da se progresivna implementacija zajedničkog tržišta ne može ometati činjenicom da je u području obrazovanja nadležnost rezervirana isključivo za države članice. Odnosno, ovom presudom Sud je implicitno priznao da obrazovanje može biti instrument za implementiranje ekonomske integracije. ${ }^{77}$ Kako smo već naveli supra, u kontekstu obrazovanja je Sud utvrdio da gospodarsku aktivnost predstavljaju one usluge koje se uobičajeno pružaju uz naknadu, pri čemu potonja zapravo predstavlja

76 Predmet 9/74 Donato Casagrande v Landeshauptstadt München [1974] ECR 773.

77 Vidi u: Gori, G., Towards a EU Right to Education, Kluwer Law International, The Hague, London - Boston, 2001., str. 26 i 27. 
ekonomsku protučinidbu za pruženu uslugu. S druge strane, uspostavljajući i održavajući javni obrazovni sustav, koji se u pravilu financira iz javnog proračuna, a ne od strane roditelja ili samih učenika, država nema namjeru obavljati djelatnosti uz naknadu, već ispunjava vlastitu zadaću koju ima prema svojem stanovništvu u obrazovnoj, socijalnoj i kulturnoj sferi. Dakle, javno (visoko) obrazovanje predstavlja negospodarsku uslugu od općeg interesa. Drugim riječima, nije riječ o području na kojem postoji tržište odnosno tržišno natjecanje. S druge strane, privatno (visoko) obrazovanje potpada pod primjenu Direktive 2006/123/EZ Europskog parlamenta i Vijeća od 12. prosinca 2006. godine o uslugama na unutarnjem tržištu (dalje u tekstu: Direktiva o uslugama $)^{78}$, i to samo u kontekstu ekonomske integracije. ${ }^{79}$ Dakle, prevladavajuće tumačenje da se Direktiva o uslugama primjenjuje samo na privatno visoko obrazovanje, a ne i na javno visoko obrazovanje. ${ }^{80}$ Drugim riječima, javno (visoko) obrazovanje nije usluga od općeg gospodarskog interesa, nego negospodarska usluga od općeg interesa na koju se ne primjenjuju pravila o tržišnom natjecanju i državnim potporama.

Naravno, treba definirati što je to javno (visoko) obrazovanje. Rodin smatra da je Europski parlament (neobvezujućom rezolucijom) postavio sljedeće kriterije: svrha aktivnosti (komercijalna ili nekomercijalna), postotak financiranja od strane javnog sektora, razina investicije, motiviranost profitom za razliku od motiva pokrivanja troškova, procjena koristi koje proizlaze iz lokalnog pribavljanja usluge za razliku od paneuropske javne nabave, jamstva socijalnih prava koja se promiču te promicanje socijalne inkluzije i integracije. ${ }^{81}$ Nadalje, važno je naglasiti da, prema praksi Suda, subjekti čiji cilj nije ostvarivanje dobiti, poput javnih obrazovnih ustanova, u određenim slučajevima mogu obavljati gospodarsku djelatnost pružanjem usluga ${ }^{82}$ Dodajmo tome i činjenicu da se obrazovne ustanove, pa i pojedini programi, mogu financirati iz različitih izvora (dijelom javnih, dijelom privatnih). Iz navedenih razloga nije lako utvrditi u kojim slučaje-

78 Službeni list Europske unije L 376/36 od 27. prosinca 2006.

79 Gori, op. cit. u bilj. 77, str. 383.

80 Hackl, E., Tensions in the Policy Objectives of the European Higher Education Area? Public Good and Public Responsibility Versus Service Liberalisation: Equality Versus Institutional Diversity u: Curaj, A.; Scott, P.; Vlaseceanu, L.; Wilson, L. (ur.), European Higher Education at the Crossroads: Between the Bologna Process and National Reforms, Springer, Dordrecht - Heidelberg - New York - London, 2012., str. 88.

81 Rodin, S., Kao brodovi u noći: hrvatsko visoko obrazovanje i slobode unutarnjeg tržišta Europske unije, Politička misao, vol. 48, br. 1, 2011., str. 190.

82 Vidi predmet C-281/06 Hans-Dieter Jundt and Hedwig Jundt v Finanzamt Offenburg [2007] ECR I-12231 točka 33. 
vima neka obrazovna ustanova, čiji je osnivač subjekt javnog prava, ipak obavlja gospodarsku djelatnost. Još je teže utvrditi predstavlja li (djelomično) financiranje obrazovnih programa koje takva ustanova pruža zabranjenu državnu potporu. Isto se pitanje javlja kod utvrđivanja usklađenosti općeg regulatornog okvira koji uređuje obrazovni sustav u Republici Hrvatskoj i tržišnih pravila EU-a o slobodi pružanja usluga. Tako se u literaturi javilo pitanje sadržava li hrvatsko zakonodavstvo nedopuštena ograničenja poslovnog nastana visokoškolskih institucija u hrvatskom pravu. ${ }^{83}$ Budući da naše zakonodavstvo u području obrazovanja, za razliku od, primjerice, javnog prijevoza, ne sadržava jasne kriterije kojima bi se utvrdilo primjenjuju li se tržišna pravila EU-a ili ne, preostaje nam utvrđivanje od slučaja do slučaja, što svakako nije najbolje rješenje iz perspektive pravne sigurnosti. U nacionalnom zakonodavstvu koje uređuje sustav obrazovanja potrebno je napraviti jasnu distinkciju između gospodarskih i negospodarskih usluga od općeg interesa kako bi se povećala pravna sigurnost i izbjegle sumnje o nelegalnom državnom favoriziranju javnih ustanova na štetu privatnih. Načelno govoreći, mislimo da postoje djelatnosti kojima se bave obrazovne ustanove koje se moraju svrstati u gospodarske usluge od općeg interesa, za koje vrijede tržišna pravila EU-a o tržišnom natjecanju, kao što je, primjerice, pružanje usluge cjeloživotnog obrazovanja. Dodatno, među privatnim ustanovama koje pružaju uslugu obrazovanja postoji natjecanje, i na tom području također vrijede tržišna pravila EU-a. S druge strane, osnovna usluga obrazovanja koje pružaju javno financirane ustanove pripada u negospodarske usluge od općeg interesa, na koje tržišna pravila EU-a nisu primjenjiva.

\section{ZAKLJUČAK}

Usluge od općeg gospodarskog interesa iznimno su kompleksna sfera prava. One nisu definirane primarnim pravom EU-a, već je konkretno određivanje što predmetni pojam obuhvaća prepušteno autonomiji država članica. Navedena autonomija, međutim, nije apsolutna, već su okviri definirani pravom Unije, a ključan faktor pri određivanje ovih usluga predstavlja njihova gospodarska, odnosno negospodarska priroda jer su usluge od općeg gospodarskog interesa podvrgnute tržišnim pravilima EU-a, za razliku od onih negospodarskih. Sudska praksa u ovom dijelu vrlo je složena te se primjenjivost tržišnih pravila utvrđuje kazuistički.

Nadalje, u slučaju gospodarskih usluga kod kojih su zadovoljeni uvjeti iz predmeta Altmark, tržišna pravila EU-a uopće nisu primjenjiva i država može

83 Rodin, op. cit. u bilj. 81, str. 205 i 206. 
ovlastiti poduzetnika za pružanje usluge od općeg gospodarskog interesa i dati mu financijsku potporu u tu svrhu. Pri tome mora biti riječ o poduzetniku kojim se upravlja na kvalitetan način, financijska pomoć je nužna za obavljanje navedene usluge, a njezin iznos je objektivno i transparentno utvrđen. Drugo, ako tržišna pravila jesu primjenjiva, odstupanje nacionalnih pravila od tržišta ipak će se moći opravdati ako je to odstupanje nužno za ostvarenje cilja od općeg interesa radi kojeg se određena usluga pruža.

Analiza odnosa pravnog okvira EU-a i hrvatskog upravnopravnog okvira u pojedinim područjima pokazuje visok stupanj usklađenosti nacionalnog prava s tržišnim pravilima Unije. To je posebno slučaj u područjima koja su uređena detaljnijim pravilima (primjerice, o državnim potporama) sadržanim u sekundarnom zakonodavstvu EU-a. S druge strane, u područjima koja pripadaju u primarnu nadležnost država članica, poput zdravstva i obrazovanja, postoje određene dileme o usklađenosti nacionalnog i europskog prava. Smatramo da je u nacionalnom zakonodavstvu koje uređuje potonje potrebno napraviti jasnu distinkciju između gospodarskih i negospodarskih usluga od općeg interesa kako bi se povećala pravna sigurnost i izbjegle sumnje o nelegalnom državnom favoriziranju javnih ustanova na štetu privatnih.

\section{LITERATURA}

Baquero Cruz, J., Beyond Competition: Services of General Interest and European Community Law, u: de Burca, G., (ur.), EU Law and the Welfare State: In Search of Solidarity, Oxford University Press, Oxford, 2005., str. 169-212.

Bruzzone, G., Moccaccio M., Infrastructure Financing and State Aid Control: The Potential for a Virtuous Relationship, u: Nascimbene, B., Di Pascale, A. (ur.), The Modernisation of State Aid for Economic and Social Development, Springer, Cham, 2018., str. 123-146.

Cerovac, M, Pojam poduzetnika u pravu tržišnog natjecanja, Hrvatska pravna revija, br. 10, 2005., str. 60-70.

Delač, Ž., Priprema i provedba četvrtoga željezničkog paketa, Željeznice, vol. 16, br. 3, 2017., str. 23-29.

Fiedziuk, V., Putting services of general economic interest up for tender: Reflections on applicable EU rules, Common Market Law Review, vol. 50, br. 1., 2013., str. 87-114.

Gallo, D., State AIds, Social Services and Healthcare in EU Law, u: Nascimbene, B., Di Pascale, A. (ur.), The Modernisation of State Aid for Economic and Social Development, Springer, Cham, 2018., str. 267-314. 
Gori, G., Towards a EU Right to Education, Kluwer Law International, The Hague, London, Boston, 2001.

Hackl, E., Tensions in the Policy Objectives of the European Higher Education Area? Public Good and Public Responsibility Versus Service Liberalisation: Equality Versus Institutional Diversity, u: Curaj, A., Scott, P., Vlaseceanu, L., Wilson, L. (ur.), European Higher Education at the Crossroads: Between the Bologna Process and National Reforms, Springer, Dordredcht, Heidelberg, New York, London, 2012., str. 83-99.

Hatzopoulos, V., Killing National Health and Insurance Systems but healing Patients? The European Market for Health Care Services after the Judgements of the ECJ in Vanbraekel and Peerbooms, Common Market Law Review, vol. 39, br. 4., 2002., str. 683-729.

HŽ Infrastruktura d.o.o., Godišnje izvješće 2018., dostupno na: http://www.hzinfra. hr/wp-content/uploads/2019/07/Godisnje-izvjesce-HZI-2018.pdf

Klarić, M.; Nikolić, M., Ustrojstvo javnih službi u Europskom pravnom poretku, Zbornik radova Pravnog fakulteta u Splitu, vol. 48, br. 1, 2011., str. 89-102.

Kovač, N., Financiranje zdravstva - situacija u Hrvatskoj, Ekonomski vjesnik, vol. 26, br. 2, 2013., str. 551-563.

Louri, V., The FENIN Judgment: The Notion of Undertaking and Purchasing Activity, Legal Issues of Economic Integration, vol. 32, 2005., str. 87-97.

Mandić, N.; Amižić Jelovčić, P., Novine u Zakonu prijevozu u linijskom i povremenom obalnom pomorskom prometu iz 2013. godine, Poredbeno pomorsko pravo, vol. 53, br. 168, 2014., str. 127-142.

Naletina, D.; Vuletić, A.; Meštrović, L., Analiza poštanskog tržišta u Republici Hrvatskoj, Zbornik Veleučilišta u Rijeci, vol. 7, br. 1, 2019., str. 301-315.

Odudu, O., Are State-Owned Health-Care Providers Undertakings Subject to Competition Law?, European Competition Law Review, vol. 48, br. 5, 2011., str. 231-241.

Poščić, A., Pojam poduzetnika u europskom pravu tržišnog natjecanja, Zbornik Pravnog fakulteta Sveučilišta u Rijeci, vol. 29, br. 2, 2008., str. 917-939.

Rodin, S., Kao brodovi u noći: hrvatsko visoko obrazovanje i slobode unutarnjeg tržišta Europske unije, Politička misao, vol. 48, br. 1, 2011., str. 190.

Sauter, W., Services of general economic interest and universal service in EU law, TILEC Discussion Paper, 2008.

Sokol, T.; Staničić, F., Pravni položaj Katoličke Crkve kao gospodarskog subjekta u pravu Europske unije i hrvatskom pravu, Zbornik Pravnog fakulteta u Zagrebu, vol. 68, br. 1, 2018., str. 31-60. 
Stanković, D., Uloga postupka javne nabave u financiranju usluga od općeg gospodarskog interesa, Zagrebačka pravna revija, vol. 7, br. 1, 2018., str. 53-69.

Svetlicinii, A., Back to the Basics: Concepts of Undertaking and Economic Activity in the Selex Judgment, European Law Reporter, vol. 12, 2009., str. 422-427.

Szyszczak, E., Services of General Economic Interest, u: Nascimbene, B., Di Pascale, A. (ur.), The Modernisation of State Aid for Economic and Social Development, Springer, Cham, 2018., str. 91-122.

Townley, C., The Concept of an 'Undertaking': The Boundaries of the Corporation A Discussion of Agency, Employees and Subsidiaries, u: Amato, G.; Ehlermann, C., (ur.), The Concept of an 'Undertaking': The Boundaries of the Corporation - A Discussion of Agency, Employees and Subsidiaries, Hart Publishing, Oxford, 2007., str. 3-23.

Van de Gronden, J., Social Services of General Interest and EU Law, u: Szyszczak, E. et al. (ur.), Developments in Services of General Interest, T.M.C. Asser Press, The Hague, 2011., str. 123-153. 
Summary

Tomislav Sokol *

Frane Staničić**

\section{SERVICES OF GENERAL ECONOMIC INTEREST IN EU LAW AND THE CROATIAN LEGAL FRAMEWORK IN SELECTED ADMINISTRATIVE AREAS}

Regulation of services of general economic interest is a very complex area of law. They represent an extremely vital part of trade on the internal market of the European Union and of the economy of the EU as a whole. They encompass a very wide spectrum of human activities and are present in all spheres of life. There are those whose economic nature poses no dillemmas, but also those whose organisation and funding is specific and subject to special legal regulation, such as health care, education, public transport etc. EU primary law does not define them, but rather leaves it to the autonomy of the Member States. However, the said autonomy is not absolute, with the overall framework being defined by the EU. The crucial factor in this regard is the economic nature of the services in question, since only economic services fall within the ambit of EU market rules. Case-law in this area is very complex, with the applicability of market rules being determined casuistically.

In case of economic services where the Altmark criteria are fulfilled, EU internal market rules are also not applicable. Consequently, the state can entrust an undertaking with the exercise of a service of general economic interest, as well as provide it with financial assistance necessary to carry out the task with which it is entrusted. Finally, even if market rules are applicable, national divergence from the market rules can be justified if it is necessary for the exercise of the general interest in question. The aim of this paper is to analyse the regulatory framework of the European Union that defines services of general economic interest, the intersection of this concept regarding the rules on free movement, competition and state aid on the internal market of the EU, and to ascertain whether the Republic of Croatia respects the aforementioned regulatory framework and whether there are issues in domestic administrative law which need resolving.

* Tomislav Sokol, Ph. D., Senior Lecturer, Zagreb School of Economics and Management; Assistant Professor, Croatian Catholic University, Jordanovac 110, Zagreb; tsokol@zsem.hr;

ORCID ID: orcid.org/0000-0002-3592-2967

** Frane Staničić, Ph. D., Associate Professor, Faculty of Law, University of Zagreb, Sv. Ćirila i Metoda 4, Zagreb; frane.stanicic@pravo.hr;

ORCID ID: orcid.org/0000-0001-8304-7901 
The analysis has shown that the Croatian administrative legal framework is to a large extent compatible with EU law. This is especially the case in the areas regulated by EU secondary legislation, containing detailed rules on the issue of services of general economic interest. It is a somewhat different situation in the areas which primarily fall within the competence of the Member States, like health care and education. Here, it is necessary for national law to make a clear distinction between economic and non-economic services of general interest. The latter is needed to increase legal certainty and to clear doubts about the state illegally prioritising public entities over private ones.

Keywords: Altmark, education, health care, transport, services of general economic interest 
